\title{
NUTRITIONAL EVALUATION OF FORAGE CACTUS FERTIGATED WITH DOMESTIC SEWAGE EFFLUENT ${ }^{1}$
}

\author{
MARCÍRIO DE LEMOS ${ }^{2}$, MIGUEL FERREIRA NETO ${ }^{3}$, JOSÉ FRANCISMAR DE MEDEIROS ${ }^{3}$, NILDO DA SILVA \\ DIAS $^{3 *}$, ENIO FARIAS DE FRANÇA E SILVA ${ }^{4}$, RANIERE BARBOSA DE LIRA $^{5}$
}

\begin{abstract}
The northeastern semiarid region faces some of the droughts of the last centuries, resulting in serious reductions of agriculture yields. The water scarcity for agricultural requires rational use practices and reuse of water, such as use of domestic effluent sewage. Alternatively, the use of treated domestic sewage effluent utilizing for irrigation of forage species, such as the forage cactus, can be highlighted. In order to evaluate the effects of fertirrigation with treated sewage effluent on mineral nutrient composition of forage cactus (Opuntia Tuna L. Mill, Mexican elephant ear), an experiment was carried out utilizing a split plot $3 \times$ ( 4 +1 ) with a randomized complete block design randomized block and four replications, being three planting density $\left(66,667.00,52,282.00\right.$ and 33,333.00 plants ha $\left.^{-1}\right)$ and two water sources associated with irrigation frequency of plates fixed on $3.5 \mathrm{~mm}$ per irrigation (Frequencies of 2.3 days with water tap and 7, 14 and 21 days with Sewage Effluent) and cactus cultivated in Rainfed agriculture rainfed (control). The analyze of the nutritional contents of cladodes indicated that there was a significant effect of the intervals from irrigation events only for $\mathrm{Ca}$ and $\mathrm{Mg}$ concentrations. The highest levels of $\mathrm{Ca}$ and $\mathrm{Mg}$ were found with the irrigation frequency of 2.3 using tap water. The macronutrients concentration in greater quantity by the forage cactus were $\mathrm{N}$ e, $\mathrm{K}$ followed by, $\mathrm{Ca}, \mathrm{Mg}$ and $\mathrm{P}$. The nutritional balance indicated excess of $\mathrm{K}$ and $\mathrm{P}$ and deficiency of $\mathrm{N}, \mathrm{Ca}$ and $\mathrm{Mg}$, in this order.
\end{abstract}

Keywords: Water reuse. Opuntia Tuna L. Mill. Nutrient uptake.

\section{AVALIAÇÃO NUTRICIONAL DA PALMA FORRAGEIRA FERTIRRIGADA COM EFLUENTE DE ESGOTO DOMÉSTICO}

RESUMO - O semiárido nordestino enfrenta umas das mais severas secas dos últimos séculos, resultando em reduções severas na produção agrícola. A escassez hídrica na agricultura exige práticas de uso racional e reaproveitamento da água como, por exemplo, a utilização de efluentes de esgoto doméstico . Alternativamente pode-se destacar o uso de esgoto doméstico tratado para irrigação de espécies forrageiras, como a palma. Objetivando avaliar os efeitos da fertirrigação com efluente de esgoto doméstico tratado sob a composição mineral de nutriente em palma forrageira (Opuntia Tuna L. Mill, Orelha-de-elefante Mexicana), foi conduzido um experimento em blocos casualizados em esquema de parcelas subdivididas $3 \times(4+1)$, com 4 repetições, sendo três densidades de plantio (66.667,00; 52.282,00 e 33.333,00 plantas ha ${ }^{-1}$ ) e duas fontes hídrica associadas a frequência de irrigação com lâmina fixa de 3,5 mm por rega (Frequências de 2,3 dias com água de abastecimento e de 7, 14 e 21 dias com Efluente de Esgoto) e, palma cultivada em sequeiro (testemunha). As análises dos teores nutricionais dos cladódios indicam que houve efeito significativo dos intervalos entre eventos de irrigação apenas para as concentrações de $\mathrm{Ca}$ e $\mathrm{Mg}$. Os maiores teores de $\mathrm{Ca}$ e $\mathrm{Mg}$ foram encontrados com a frequência de irrigação de 2,3 utilizando água de abastecimento. Os macronutrientes em maior quantidade pela palma forrageira foram $\mathrm{N}$ e $\mathrm{K}$ seguido de $\mathrm{Ca}, \mathrm{Mg}$ e $\mathrm{P}$. O balanço nutricional indicou excesso de $\mathrm{K}$ e $\mathrm{P}$ e déficit de $\mathrm{N}$, Ca e $\mathrm{Mg}$, nesta ordem.

Palavras-chave: Reúso de água. Opuntia Tuna L. Mill. Absorção de nutrientes.

\footnotetext{
*Corresponding author

${ }^{1}$ Received for publication in $12 / 20 / 2016$; accepted in $05 / 30 / 2017$.

Paper extracted from the first author's doctoral's thesis.

${ }^{2}$ Terra Viva Cooperative, Mossoró, RN, Brazil; marcirio@hotmail.com.

${ }^{3}$ Center of Agrarian Science, Universidade Federal Rural do Semi-Árido, Mossoró, RN, Brazil; miguel@ufersa.edu.br, jfmedeir@ufersa.edu.br,nildo@ufersa.edu.br.

${ }^{4}$ Universidade Federal Rural de Pernambuco, Recife, PE, Brazil; enio.fsilva@ufrpe.br.

${ }^{5}$ Coopervida Cooperative, Mossoró, RN, Brazil; ranierejunco@gmail.com.
} 


\section{INTRODUCTION}

The Northeastern semiarid zone of Brazil, faces serious cyclic water crisies due to its geographic position and meteorological processes. Currently, this region has faced the most severe drought of the last few centuries, with impacts on the primary production due to its dependence on water in these areas.

One opportunity the water crisis provides are conditions suitable for the adoption of techniques compatible with the maximizing water potential including, catchment and conservation techniques and reuse strategies. One of these strategies involves the reuse of treated domestic sewage in agriculture, especially in the production of forage and ornamental species.

The reuse of treated sewerage water may cause problems such as the contamination of soil, surface water, groundwater and toxicities to plants, so its use is highly regulated. The managed application of treated sewerage has various environmental benefits including the absorption and recycling of nutrients from the effluent into plant dry matter as well as the increased availability of water. Harvesting of the plants that have been fed the treated effluent can help to remove these elements from the soil, and avoid excessive accumulation of nutrients in the soil, especially nitrogen $(\mathrm{N})$ and potassium (K) (ERTHAL et al., 2010).

Forage cactus is demanding in nutrients and thus needs good fertilization, which is a determinant in its fresh matter production, requiring larger amounts of $\mathrm{N}$ (LOPES et al., 2013). The plant can also absorb large amounts of nutrients from the soil, which is evidenced by a dry matter (DM) production of $10 \mathrm{t} \mathrm{ha}^{-1}$ year $^{-1}$. Mean contents of $\mathrm{N}, \mathrm{P}, \mathrm{K}$ and $\mathrm{Ca}$ in the order of $0.9,0.16,2.58$ and $2.35 \%$, respectively (SANTOS et al., 1990). However, this would suggest using rates of fertilizers for DM production of $195.48,204.44$ and $737.14 \mathrm{~kg} \mathrm{ha}^{-1}$ of Urea, Monoammonium Phosphate (MAP) and Potassium Chloride $(\mathrm{KCl})$, respectively.

On the other hand, different planting densities may result in changes in the absorption and exportation of nutrients by plants, and the ideal arrangement has a direct influence on light interception, growth, yield and, consequently, the nutritional value of the produced forage (SILVA et al., 2013). Studies on planting density, fertilization and intervals between irrigation events in forage cactus cultivation in the semi-arid region aim to increase forage production, respecting the edaphoclimatic and social fragilities of the region.
Thus, the objective of this research was to evaluate the effects of fertigation with sewage sludge and planting densities on the nutritional status of forage cactus, based on the identification of the dynamics of nutrients in the soil-plant system.

\section{MATERIAL AND METHODS}

The experiment was carried out at the Settlement Project (SP) Milagres, Apodi/RN, situated $100 \mathrm{~km}$ away from the Federal Rural University of the Semi-Arid Region - UFERSA and $18 \mathrm{~km}$ away from the headquarters of the municipality of Apodi/RN, whose geographic coordinates are $5^{\circ} 35^{\prime} 17^{\prime \prime} \mathrm{S}$ and $37^{\circ} 54^{\prime} 07^{\prime \prime} \mathrm{W}$. The SP has 28 households, which have a sewage collection and interception network.

The adopted experimental design was randomized blocks in $3 \times(4+1)$ split-plot scheme, with three planting densities: $0.10 \times 0.80 \times 2.20 \mathrm{~m}$, $0.13 \times 0.80 \times 2.20 \mathrm{~m}$, and $0.20 \times 0.80 \times 2.20 \mathrm{~m}$ $\left(66,667,52,282\right.$ and 33,333 plants $\mathrm{ha}^{-1}$, respectively), comprising the main treatments. Treatments were two different water sources associated with four irrigation frequencies with fixed water depth of $3.5 \mathrm{~mm}$ per irrigation event: frequencies of 2.3 days with the public-supply water and 7, 14 and 21 days with sewage effluent, comprised the subplot. The control treatment was forage cactus cultivation under rainfed conditions, applied in four replicates.

The results of physical-chemical and biological analysis of the public-supply water (PSW) and domestic sewage effluent (DSE) used in the experiment are shown in Table 1.

Forage cactus was cultivated on an Argisol and tillage consisted of plowing and harrowing. Planting furrows were opened using a three-shank cultivator attached to a tractor, with spacing of $0.40 \mathrm{~m}$ between shanks and a furrow depth of $0.15 \mathrm{~m}$. Side furrows were used to plant the cladodes, while central furrows were used to conduct irrigation water. Basal fertilization consisted of $30 \mathrm{t} \mathrm{ha}^{-1}$ of manure from dairy cows.

The forage cactus nutrient requirement was estimated using a regression calculation, considering the exportation of nutrients recommended in the literature, chemical composition and efficiency of the nutrients (NPK), which led to the following values: $715.34 \mathrm{~kg} \mathrm{ha}^{-1}$ of nitrogen $(\mathrm{N}), 189.40 \mathrm{~kg} \mathrm{ha}^{-1}$ of phosphorus (P) and $1,602.96 \mathrm{~kg} \mathrm{ha}^{-1}$ of potassium $(\mathrm{K})$ for an estimated flesh matter production of $40 \mathrm{tha}^{-1}$, and with a DM content estimated to equal 10\% (SANTOS et al., 1990; DONATO et al., 2017). 
Table 1. Physical-chemical and biological analysis of the domestic sewage effluent (DSE) and public-supply water (PSW) from Settlement Project (SP).

\begin{tabular}{|c|c|c|}
\hline \multirow{2}{*}{ Parameters } & \multicolumn{2}{|c|}{ Water sources } \\
\hline & DES & PSW \\
\hline 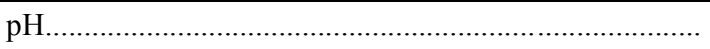 & 7.34 & 7.00 \\
\hline Electric Conductivity - EC $\left(\mathrm{dS} \mathrm{m}^{-1}\right) \ldots$ & 1.10 & 0.09 \\
\hline 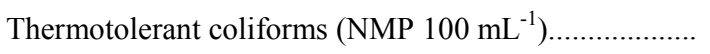 & $9.8 \times 10_{3}$ & 0 \\
\hline 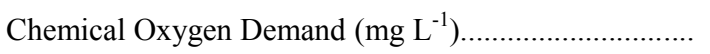 & 80 & - \\
\hline Biochemical oxygen demand $\left(\mathrm{mg} \mathrm{L}^{-1}\right) \ldots$ & 27 & - \\
\hline Total solids $\left(\mathrm{mg} \mathrm{L}^{-1}\right) \ldots \ldots \ldots \ldots \ldots$ & 655 & - \\
\hline Suspended solids $\left(\mathrm{mg} \mathrm{L}^{-1}\right) \ldots \ldots$ & 44.0 & - \\
\hline Phosphorus $\left(\mathrm{mg} \mathrm{L}^{-1}\right) \ldots \ldots \ldots \ldots \ldots . . . .$. & 7.8 & - \\
\hline Nitrogen $\left(\mathrm{mg} \mathrm{L}^{-1}\right) \ldots \ldots \ldots \ldots \ldots \ldots$ & 54.1 & - \\
\hline Potassium $\left(\mathrm{mg} \mathrm{L}^{-1}\right) \ldots \ldots \ldots . .$. & 23.7 & 11.5 \\
\hline Iron $\left(\mathrm{mg} \mathrm{L}^{-1}\right) \ldots \ldots \ldots \ldots \ldots$ & 0.48 & 0.26 \\
\hline Manganese $\left(\mathrm{mg} \mathrm{L}^{-1}\right) \ldots .$. & 0.13 & 0.05 \\
\hline $\operatorname{Zinc}\left(\mathrm{mg} \mathrm{L}^{-1}\right) \ldots$ & 0.08 & 0.2 \\
\hline Copper $\left(\mathrm{mg} \mathrm{L}^{-1}\right) \ldots$ & 0.04 & 0.03 \\
\hline Sodium $\left(\mathrm{mmolc} \mathrm{L}^{-1}\right) \ldots \ldots \ldots$ & 7.03 & 0.46 \\
\hline Calcium $\left(\right.$ mmolc $\left.^{-1}\right) \ldots \ldots \ldots \ldots \ldots \ldots \ldots \ldots$ & 1.21 & 0.17 \\
\hline 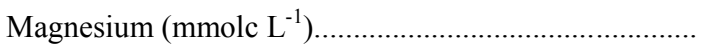 & 0.76 & 0.28 \\
\hline Chloride $\left(\mathrm{mmolc} \mathrm{L}^{-1}\right) \ldots \ldots \ldots \ldots \ldots \ldots \ldots \ldots$ & 2.30 & 0.88 \\
\hline
\end{tabular}

The planting material was pre-selected from cladodes of Opuntia Tuna L. Mill, variety 'Orelha de Elefante Mexicana', which were rested in the shade for two weeks prior to planting. Planting was performed 90 days before the beginning of the rainy period. The cladodes were planted in the furrows, lined up (domino), facing the East-West direction and half-buried.

Disturbed soil samples were collected from $0-0.20 \mathrm{~m}$ for initial characterization of the physical-chemical attributes (Table 2). Soil samples were analyzed at the UFERSA's Laboratory of Soil Fertility and Plant Nutrition (EMBRAPA, 1997).

Table 2. Physical-chemical properties of experimental field soils before of the application of the domestic sewage effluent.

\begin{tabular}{|c|c|c|c|c|c|c|c|c|c|c|c|c|c|c|}
\hline \multirow{2}{*}{ Layer (m) } & \multirow{2}{*}{$\begin{array}{l}\text { OM } \\
\mathrm{g} \mathrm{kg}^{-1}\end{array}$} & \multirow[t]{2}{*}{$\mathrm{pH}$} & $\mathrm{K}$ & $\mathrm{Na}$ & $\mathrm{N}$ & B & $\mathrm{Cu}$ & $\mathrm{Zn}$ & $\mathrm{Ca}$ & $\mathrm{Mg}$ & $\overline{\mathrm{Al}}$ & SB & CEC & \multirow{2}{*}{$\begin{array}{l}\mathrm{M} \\
\%\end{array}$} \\
\hline & & & $\ldots$ & &.. $\mathrm{mg} \mathrm{d}$ & -3 & & . & $\ldots$ & $\ldots . . \mathrm{cr}$ & $\mathrm{dm}^{-}$ & & $\cdots$ & \\
\hline $0-0.20$ & 1.8 & 7.7 & 138 & 125 & 0.25 & 0.3 & 0.7 & 3.1 & 2.1 & 0.6 & 0.0 & 3.0 & 4.04 & 0 \\
\hline
\end{tabular}

An adapted furrow irrigation system was used, referred to as modified low-head gravity bubbler irrigation system. Planting furrows were supplied with water from microtubes inserted in the polyethylene lateral lines (3/4"), which were buried at depth of $10 \mathrm{~cm}$. The system operated at pressure of 2 mwc and did not require pumping, eliminating losses through conduction and minimizing losses through percolation, because the water was applied in furrows. Half of the local daily ETo was used as a parameter for irrigation, defining a fixed water depth of $3.5 \mathrm{~mm}$ per irrigation event.

At 375 days after planting (DAP), tissue samples from mature cladodes were collected to evaluate mineral composition characteristics. After collection, the samples were sliced and $2.0 \mathrm{~kg}$ of fresh matter were weighed and dried in a forced-air oven at $65{ }^{\circ} \mathrm{C}$ until constant weight. After drying, the samples were ground in a Wiley-type mill with 1-mm-mesh sieve, identified, stored in plastic pots and analyzed at the Laboratory of Soil and Plant Nutrition of the Center of Agricultural Sciences of the UFERSA.

The following contents were determined: Nitrogen $(\mathrm{N})$, Phosphorus $(\mathrm{P})$, Potassium (K), Calcium (Ca), Sodium (Na), Magnesium (Mg), Iron $(\mathrm{Fe})$, Manganese $(\mathrm{Mn})$, Zinc $(\mathrm{Zn})$ and Copper $(\mathrm{Cu})$. For $\mathrm{N}$ determination, the sample was digested using sulfuric acid $\left(\mathrm{H}_{2} \mathrm{SO}_{4}\right)$ in digestion blocks at temperature of $300{ }^{\circ} \mathrm{C}$ for two hours (TEDESCO et al., 1995). Total $\mathrm{N}$ was quantified through the steam distillation. The other macro- and micronutrients were determined through wet digestion in closed system, using a microwave oven as heat source and 
concentrated $\mathrm{HNO}_{3}$ to digest the dry matter.

The results were subjected to analysis of variance by the Fisher test with minimum significance level of 0.05 and the treatment means were compared by Tukey test at 0.05 probability level. All analyses were performed with the program SISVAR version 5.6 to verify the significance of the studied factors.

\section{RESULTS AND DISCUSSION}

\section{Nitrogen concentration in cladodes}

The $\mathrm{N}$ in the forage cactus did not fit into any of the tested regression models, exhibiting an overall mean of $26.33 \mathrm{~g} \mathrm{~kg}^{-1}$. Maximum $\mathrm{N}$ export was obtained by the product between mean values of $\mathrm{N}$ export $\left(26.33 \mathrm{~g} \mathrm{ha}^{-1}\right)$ and total dry matter production $\left(69.39 \mathrm{t} \mathrm{ha}^{-1}\right)$, at $375 \mathrm{DAP}$, and was equal to $1,827.03 \mathrm{~kg} \mathrm{ha}^{-1}$. The average $\mathrm{N}$ exportation was $263.30 \mathrm{~kg} \mathrm{ha}^{-1}$ for every $10 \mathrm{t} \mathrm{ha}^{-1}$ of dry matter (Figure 1).

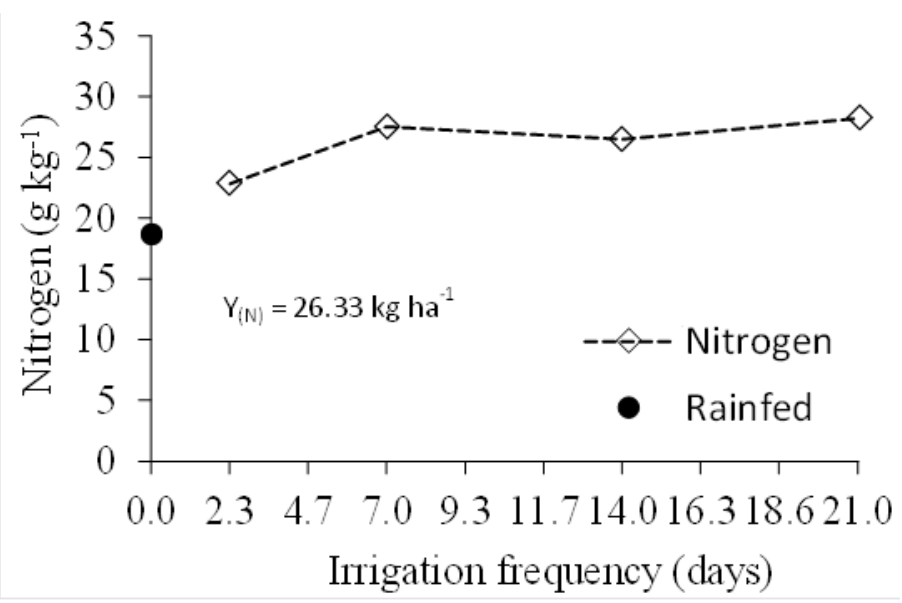

Figure 1. Nitrogen concentration of forage cactus plants (cladodes) at 375 DAP differing in irrigation frequency.

The addition of $\mathrm{N}$ sources to the soil under the forage cactus cultivation, was from basal fertilization with bovine manure and fertigation with domestic sewage effluent. Both helped to increase the content and availability of $\mathrm{N}$ in the soil and, consequently, led to the incremental absorption of $\mathrm{N}$ by the forage cactus. Donato et al. (2016) studied the effects of different doses of approximately $131.65 \mathrm{~kg} \mathrm{ha}^{-1} \mathrm{~N}$ for every $10 \mathrm{t} \mathrm{ha}^{-1}$ of dry matter. Souza (2015), in an experiment with NPK fertilization at 620 days after planting, found that the mean export of $\mathrm{N}$ was $177.88 \mathrm{~kg} \mathrm{ha}^{-1}$ for every $10 \mathrm{t} \mathrm{ha}^{-1}$ of dry matter. Although both these studies reported similar results, the values were below those found in the present study and the time after planting was twice as long. However, the $\mathrm{N}$ contents found in the present study are close to the results reported by Dubeux Júnior et al. (2010), who observed $20.60 \mathrm{~g} \mathrm{~kg}^{-1}$ of $\mathrm{N}$, resulted from the evaluation of phosphorus and potassium levels in a greenhouse at 120 days, with fixed $\mathrm{N}$ doses.

Only the irrigation interval of 21 days with sewage effluent showed significant statistical difference $(\mathrm{P}<0.05)$ from the control (rainfed cultivation) for export of $\mathrm{N}$ to the cladodes at 375 DAP, demonstrating the treatment with the lowest frequency of irrigation and sewage effluent, led to higher $\mathrm{N}$ absorption by the plant.

However, considering the mean DM production and the export of the nutrient at 375 DAP, the values were high, on the order of $1,289.01$, $2,130.94,1,748.05$ and $1,191.01 \mathrm{~kg} \mathrm{ha}^{-1}$ of $\mathrm{N}$ in the irrigation intervals of $2.3,7,14$ and 21 days, respectively. Donato et al. (2017) studied different doses of bovine manure and planting densities, and found mean export of $\mathrm{N}$ was $240.1 \mathrm{~kg} \mathrm{ha}^{-1}$ at 600 DAP. Souza (2015), in an experiment with NP and NPK fertilization, found a mean extraction/export of $304.35 \mathrm{~kg} \mathrm{ha}^{-1}$ of $\mathrm{N}$ at $620 \mathrm{DAP}$.

In this experiment, the planting densities did not significantly influence $\mathrm{N}$ exports with the respective irrigation intervals. Although $\mathrm{N}$ is considered highly mobile in the soil and its absorption by plants preferentially occurs through mass flow, the combination of basal fertilization and fertigation with treated domestic sewage were sufficient to inhibit the competition between the root systems caused by increased planting density.

\section{Phosphorus concentration in cladodes}

According to Figure 2, the export of $\mathrm{P}$ via the cladodes in the forage cactus did not fit to any of the tested regression models. The overall mean of extraction of $\mathrm{P}$ was equal to $0.36 \mathrm{~g} \mathrm{~kg}^{-1}$ in dry matter. The maximum export of $\mathrm{P}$, obtained by the product between the mean $\mathrm{P}$ exportation $\left(0.36 \mathrm{~g} \mathrm{ha}^{-1}\right)$ and total dry matter production $\left(69.39 \mathrm{t} \mathrm{ha}^{-1}\right)$, at 375 DAP, was $24.98 \mathrm{~kg} \mathrm{ha}^{-1}$, with mean export of $\mathrm{P}$ at $3.60 \mathrm{~kg} \mathrm{ha}^{-1}$ for every $10 \mathrm{t} \mathrm{ha}^{-1}$ of dry matter. 


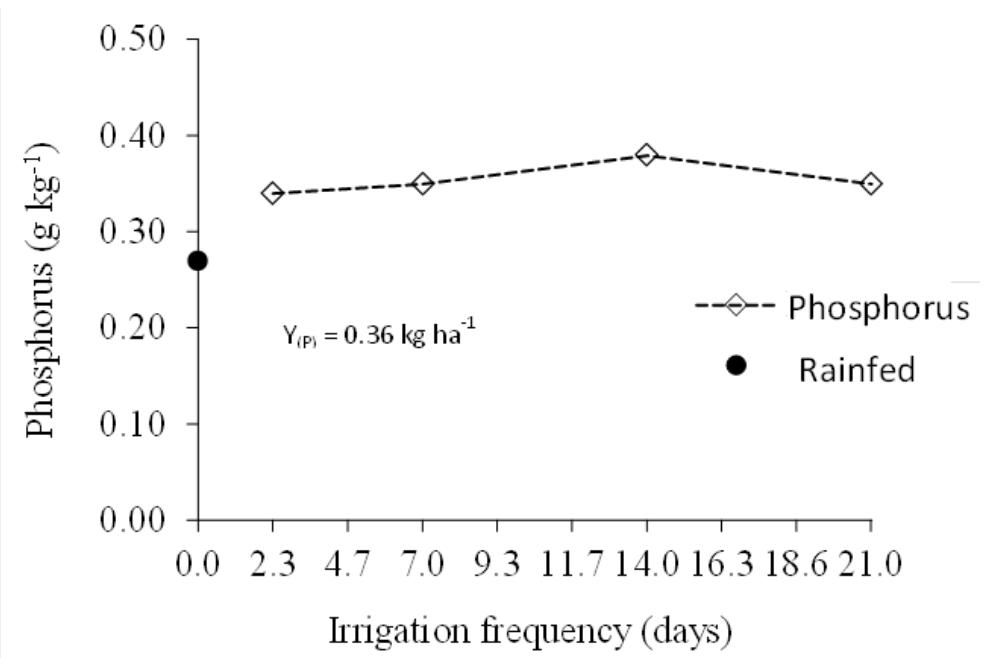

Figure 2. Phosphorus concentration of forage cactus plants (cladodes) at 375 DAP differing in irrigation frequency.

Other research by Teles et al. (2002) and Dubeux Júnior et al. (2010), also evaluated phosphate fertilization levels in forage cactus cultivation and found mean $\mathrm{P}$ contents higher than those in the present study (1.7 and $4.7 \mathrm{~g} \mathrm{~kg}^{-1}$, respectively), with minimum and maximum limits of between 3.9 and $5.7 \mathrm{~g} \mathrm{~kg}^{-1}$, respectively. The low $\mathrm{P}$ contents in the cladodes observed in the present study may result from the small initial dose of $\mathrm{P}$ used, compared to the other studies, or also because the other studies were conducted in pots, where the nutrient may have been more concentrated in the soil mass due to low mobility in the soil, and where the root system may have acted better in the absorption of this element.

The irrigation intervals did not differ significantly $(\mathrm{P}<0.05)$ effect the export of $\mathrm{P}$ from the soil to the DM, at 375 DAP when compared to the rainfed treatment in the forage cactus. This deficiency of $\mathrm{P}$ the soil could be due to the low level of $\mathrm{P}$ nutrient in the basal fertilizer and in the fertigation and, consequently, in its export from the soil by the forage cactus. Likewise, it corroborates with the low $\mathrm{P}$ availability in the soil, and in the other irrigation intervals which were not sufficient to supply $\mathrm{P}$ forms precipitated with other elements, such as iron (Fe), as commonly found in the soils of the region of the experiment.

It is also important to consider that $\mathrm{P}$ has low mobility in the soil and its preferential transport is through diffusion, which occurs through a gradient of content between the rhizosphere and the surrounding areas (ERNANI et al., 2007). Hence, the low $\mathrm{P}$ availability in the entire soil compromises even more its absorption by forage cactus roots.

Based on the mean values of dry matter production, the contents of the nutrient at 375 DAP were in the order of $19.14,27.06,25.02$ and $14.73 \mathrm{~kg}$ $\mathrm{ha}^{-1}$ of $\mathrm{P}$ in the irrigation intervals treatments of 2.3 , 7, 14 and 21 days, respectively; i.e., $3.40,3.50,3.80$ and $3.50 \mathrm{~kg} \mathrm{ha}^{-1}$ of $\mathrm{P}$ for every $10 \mathrm{tha}^{-1}$ of dry matter in the irrigation intervals at $375 \mathrm{DAP}$, respectively.

Donato et al. (2017) evaluated the effects of bovine manure doses and tree spacing, and observed a mean $\mathrm{P}$ exportation of $35.3 \mathrm{~kg} \mathrm{ha}^{-1}$ at 600 DAP. However, the highest export of $\mathrm{P}$ from the soil to the plant occurred at the spacing of $1.0 \times 0.5 \mathrm{~m}$ $\left(40.3 \mathrm{~kg} \mathrm{ha}^{-1}\right)$. However, the harvest was performed two years after planting and the nutrient contents found at 375 DAP were doubled.

The lowest $\mathrm{P}$ content was recorded at the spacing of $3.0 \times 1.0 \times 0.25 \mathrm{~m}\left(28.2 \mathrm{~kg} \mathrm{ha}^{-1}\right)$. Souza (2015) obtained mean P exportations of 20.16, 20.74, $21.95 \mathrm{~kg} \mathrm{ha}^{-1}$, respectively, in experiment with $\mathrm{P}, \mathrm{NP}$ and NPK fertilization at 620 DAP. These results were similar to those of the present study, but higher than the extraction/export of $\mathrm{P}$ at $12.37 \mathrm{~kg} \mathrm{ha}^{-1}$, obtained with the treatment without fertilization. The addition of fertilizers favored $\mathrm{P}$ exportation and the mean value was $18.81 \mathrm{~kg} \mathrm{ha}^{-1}$, when compared to a treatment without fertilization.

The planting densities did not influence $P$ exportation with the respective irrigation intervals. Hence, since the limitation of $\mathrm{P}$ is generalized through the entire soil, there was no influence of planting density and, consequently, competition between roots to influence the absorption and exportation of the nutrient.

\section{Potassium concentration in cladodes}

It can be noted that $\mathrm{K}$ export did not fit to any of the tested regression models and its overall mean was $22.99 \mathrm{~g} \mathrm{~kg}^{-1}$ of dry matter. The maximum $\mathrm{K}$ exported at 375 DAP was $1,595.27 \mathrm{~kg} \mathrm{ha}^{-1}$, with mean export of $\mathrm{K}$ being $229.90 \mathrm{~kg} \mathrm{ha}^{-1}$ for every $10 \mathrm{tha}^{-1}$ of dry matter (Figure 3).

The observed values confirmed that there was elevated $\mathrm{K}$ extraction by the plant, even when compared with the other nutrients evaluated. The $\mathrm{K}$ contents were similar to those found by Santos et al. (1990) $\left(25.8 \mathrm{~g} \mathrm{~kg}^{-1}\right)$ but lower than those found by 
Dubeux Júnior et al. (2010), who worked with four K levels $\left(0 ; 200 ; 400\right.$ and $800 \mathrm{~kg} \mathrm{ha}^{-1}$ of $\left.\mathrm{K}_{2} \mathrm{O}\right)$ and observed overall mean of $33.4 \mathrm{~g} \mathrm{~kg}^{-1}$, with variations from 19.4 to $59.0 \mathrm{~g} \mathrm{~kg}^{-1}$.

However, Donato et al. (2016) studied the effects of bovine manure doses and planting densities in forage cactus cultivation and obtained, at
600 DAP, an overall mean extraction/export of 394.54 of $\mathrm{K} \mathrm{kg} \mathrm{ha}^{-1}$ for every $10 \mathrm{t} \mathrm{ha}^{-1}$ of dry matter. In another experiment, Souza (2015), found mean K exports of $246.07 \mathrm{~kg} \mathrm{ha}^{-1}$ for every $10 \mathrm{t} \mathrm{ha}^{-1}$ of dry matter production in an experiment with NPK fertilization applied over 620 DAP.

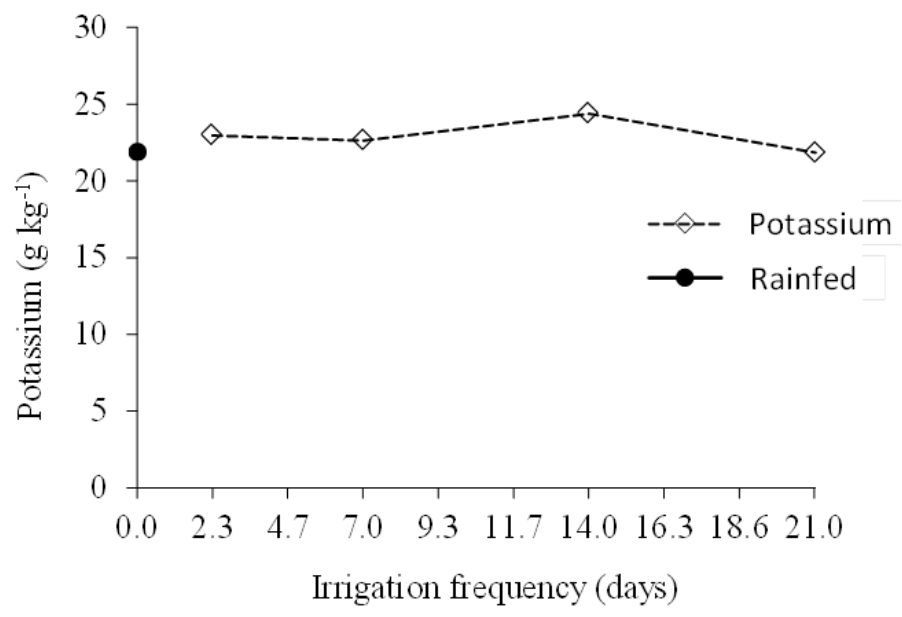

Figure 3. Potassium concentration of forage cactus plants (cladodes) at 375 DAP differing in irrigation frequency.

None of the irrigation intervals showed significant statistical differences $(\mathrm{P}<0.05)$ from the treatment with rainfed cultivation for $\mathrm{K}$ extraction at 375 DAP, which demonstrates the low contents of this nutrient in the basal fertilization and fertigation for the accumulation of $\mathrm{K}$ in the soil and, consequently, its exportation by the plant. However, considering the mean values of dry matter production, the export of this nutrient at 375 DAP were in the order of 1,295.26, 1,777.69, 1,608.06 and $920.48 \mathrm{~kg} \mathrm{ha}^{-1}$ in the irrigation intervals of $2.3,7,14$ and 21 days, respectively. In other words, 230.1, $226.7,244.2$ and $218.7 \mathrm{~kg} \mathrm{ha}^{-1}$ of $\mathrm{K}$ were extracted by the plant for every $10 \mathrm{tha}^{-1}$ of dry matter in the irrigation intervals at 375 DAP, respectively.

Donato et al. (2017) studied bovine manure doses and spacing and obtained a mean $\mathrm{K}$ content of $714.50 \mathrm{~kg} \mathrm{ha}^{-1}$ at 600 DAP. The maximum $\mathrm{P}$ exportation (935.5 $\mathrm{kg} \mathrm{ha}^{-1}$ ) was obtained with the application of $83.3 \mathrm{t} \mathrm{ha}^{-1}$ year $^{-1}$ of manure. Souza (2015), in experiment with NPK fertilization at 620 DAP, obtained mean extraction of $421.04 \mathrm{~kg} \mathrm{ha}^{-1}$ of $\mathrm{P}$. The maximum $\mathrm{K}$ exportation by forage cactus occurred in the treatment of maximum chemical fertilization with $\mathrm{K}$, equal to $504.01 \mathrm{~kg} \mathrm{ha}^{-1}$.

\section{Calcium concetration in cladodes}

According to Figure 4, Ca exports fitted a quadratic regression model and the equation of the line resulted in irrigation interval of 17.11 days. The model estimated a maximum $\mathrm{Ca}$ exportation of $18.40 \mathrm{~g} \mathrm{~kg}^{-1}$ of dry matter and total $\mathrm{Ca}$ exportation of $1,110.35 \mathrm{~kg} \mathrm{ha}^{-1}$ by the forage cactus, based on the total dry matter production.

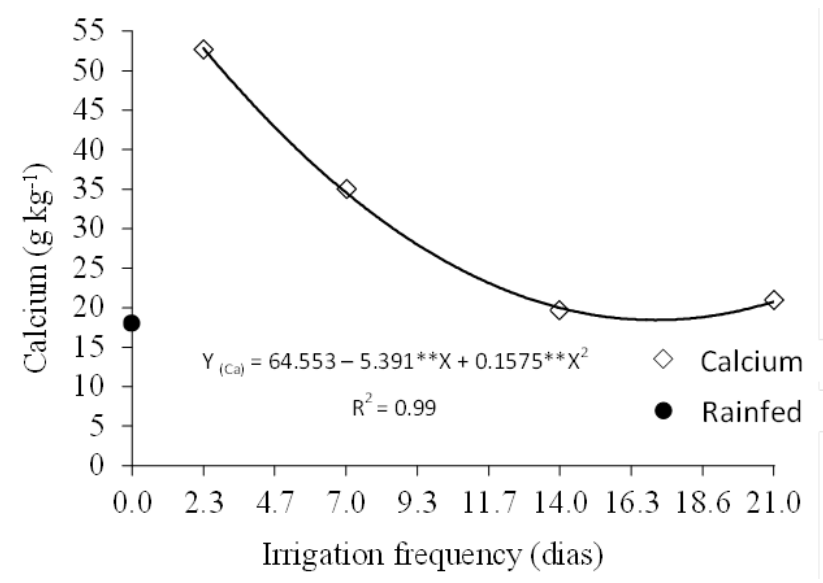

Figure 4. Calcium concentration of forage cactus plants (cladodes) at 375 DAP differing in irrigation frequency. 
These results are close to those of Teles et al. (2004), with variation from 15.6 to 21.0 and a mean of $18.4 \mathrm{~g} \mathrm{ha}^{-1}$, and lower than those of Dubeux Júnior et al. (2010), who observed a mean value of $34.4 \mathrm{~g} \mathrm{~kg}^{-1}$. On the other hand, Donato et al. (2016) obtained, at 600 DAP, overall mean of Ca extraction of $268.33 \mathrm{~kg} \mathrm{ha}^{-1}$ for every $10 \mathrm{t} \mathrm{ha}^{-1}$ of dry matter. Souza (2015), in an experiment with NPK fertilization at 620 DAP, found overall mean $\mathrm{Ca}$ extraction of $175.50 \mathrm{~kg} \mathrm{ha}^{-1}$ for every $10 \mathrm{tha}^{-1}$ of dry matter production.

Only the treatment with irrigation interval of 2.3 days irrigated using water from tubular artesian well exhibited significant statistical difference $(\mathrm{P}<0.05)$ in relation to the control (rainfed cultivation) for $\mathrm{Ca}$ exportation at $375 \mathrm{DAP}$, demonstrating that the treatment with shortest irrigation interval fertigated with domestic sewage effluent led to higher $\mathrm{Ca}$ absorption by the plant.

However, considering the mean dry matter production, the exportations of $\mathrm{Ca}$ at $375 \mathrm{DAP}$ are on the order of 2,963.36, 2,705.58, 1,290.05 and $881.05 \mathrm{~kg} \mathrm{ha}^{-1}$ in the irrigation intervals of $2.3,7,14$ and 21 days, respectively. In other words, 526.43, $349.90,195.93$ and $209.30 \mathrm{~kg} \mathrm{ha}^{-1}$ of Ca for every $10 \mathrm{t} \mathrm{ha}^{-1}$ of dry matter in the irrigation intervals at 375 DAP, respectively. The values of 526.43 and $349.90 \mathrm{~kg} \mathrm{ha}^{-1}$ exceed that described by Santos et al. (2002), of $235 \mathrm{~kg} \mathrm{ha}^{-1}$ for every $10 \mathrm{t} \mathrm{ha}^{-1}$ of dry matter.

Calcium is the nutrient extracted in largest amounts by forage cactus, followed by nitrogen and potassium. However, its content decreases with the increment in the intervals between irrigation events, regardless of the source of water. Nevertheless, the opposite occurs with nitrogen, i.e., its content increases with the increment in the interval between irrigation events.

Galizzi, Felker and Gonzalez (2004) found no correlation between the Ca contents in the cladodes and in the soil, but observed direct correlation with $\mathrm{pH}$, since the more alkaline the soil, the higher the $\mathrm{Ca}$ content in cladode tissues of the forage cactus. Contrary to this study, the results demonstrate just the opposite, because soil $\mathrm{pH}$ was highly acidic.

\section{Magnesium concentration in cladodes}

The $\mathrm{Mg}$ export in forage cactus fitted a quadratic regression model. The equation of the line resulted in an irrigation interval of 14.59 days and the model estimated maximum $\mathrm{Mg}$ exportation of $14.75 \mathrm{~g} \mathrm{~kg}^{-1}$ of dry matter and total $\mathrm{Mg}$ exportation of $1,011.21 \mathrm{~kg} \mathrm{ha}^{-1}$ in the forage cactus, based on the total dry matter production. The mean $\mathrm{Mg}$ exportation was $147.50 \mathrm{~kg} \mathrm{ha}^{-1}$ for every $10 \mathrm{t} \mathrm{ha}^{-1}$ of dry matter (Figure 5).

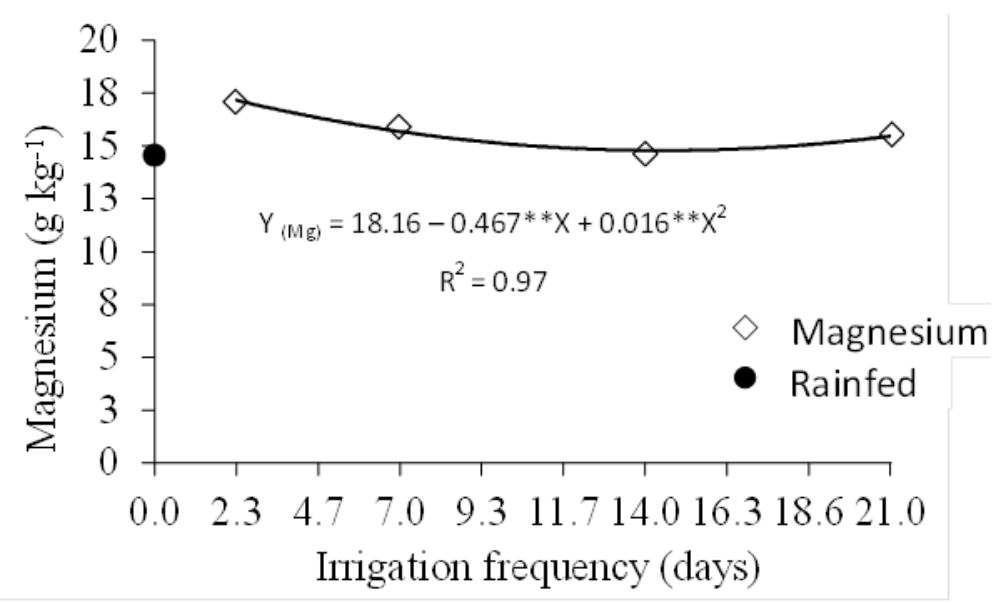

Figure 5. Magnesium concentration of forage cactus plants (cladodes) at 375 DAP differing in irrigation frequency.

The result obtained by Teles et al. (2004) was $5.9 \mathrm{~g} \mathrm{~kg}^{-1}$, which was lower than those of the present study. Alves et al. (2007) observed mean Mg content of $11.0 \mathrm{~g} \mathrm{~kg}^{-1}$ in forage cactus tissue, without significant differences between irrigation with sewage effluent and tap water. The values of the present study are close to those reported by Nobel et al. (1987), who found $\mathrm{Mg}$ contents from 6.4 to $14.2 \mathrm{~g} \mathrm{~kg}^{-1}$ with a mean value of $10.3 \mathrm{~g} \mathrm{~kg}^{-1}$ in plants of the species Opuntia engelmannii in Coahuila, Mexico. Donato et al. (2016), studying bovine manure doses and spacing, obtained an overall mean $\mathrm{Mg}$ extraction of $121.04 \mathrm{~kg} \mathrm{ha}^{-1}$ for every $10 \mathrm{t} \mathrm{ha}^{-1}$ of dry matter at 600 DAP. Souza (2015), in an experiment with NPK fertilization, found an overall mean $\mathrm{Mg}$ exportation of $125.75 \mathrm{~kg} \mathrm{ha}^{-1}$ for every $10 \mathrm{t} \mathrm{ha}^{-1}$ of dry matter at 620 DAP.

Only the irrigation interval of 14 days showed no significant statistical differences $(\mathrm{P}>0.05)$ in relation to the control under rainfed conditions but the other irrigation intervals of 2.3, 7 and 21 days did sow significant statistical difference $(\mathrm{P}>0.05)$. The treatment with longest irrigation fertigation interval and treated with domestic sewage led to higher $\mathrm{Mg}$ absorption by the plant (Figure 5).

However, considering the mean values of dry 
matter production, $\mathrm{Mg}$ extractions at $375 \mathrm{DAP}$ were in the order of $960.33,1,229.72,961.64$ and $653.74 \mathrm{~kg} \mathrm{ha}^{-1}$ in the irrigation intervals of $2.3,7,14$ and 21 days, respectively, i.e., 170.60, 159.03, 146.10 and $155.30 \mathrm{~kg} \mathrm{ha}^{-1}$ of $\mathrm{Mg}$ for every $10 \mathrm{tha}^{-1}$ of dry matter in the irrigation intervals, respectively, at 375 DAP.

Donato et al. (2017), studying bovine manure doses and tree spacing, obtained the mean $\mathrm{Mg}$ content of $207.1 \mathrm{~kg} \mathrm{ha}^{-1}$ at $600 \mathrm{DAP}$. The fitted model estimated maximum $\mathrm{Mg}$ exports of $294.5 \mathrm{~kg} \mathrm{ha}^{-1}$ at the dose of $68.7 \mathrm{t} \mathrm{ha}^{-1}$ year $^{-1}$ of manure. Souza (2015), in an experiment with N, NP and NPK fertilization at 620 DAP, obtained a mean export of $215.15 \mathrm{~kg} \mathrm{ha}^{-1}$ of $\mathrm{Mg}$. The maximum $\mathrm{Mg}$ extraction in the forage cactus occurred in the NPK treatment (000-150-000), which exported $241.25 \mathrm{~kg} \mathrm{ha}^{-1}$.

Based on the total extraction of nutrients at 375 DAP, the macronutrient extracted in largest amounts was nitrogen, with $1,827.03 \mathrm{~kg} \mathrm{ha}^{-1}$, followed by potassium with $1,595.27 \mathrm{~kg} \mathrm{ha}{ }^{-1}$, calcium with $1,110.35 \mathrm{~kg} \mathrm{ha} \mathrm{ha}^{-1}$ magnesium with $1,011.21 \mathrm{~kg} \mathrm{ha}^{-1}$ and phosphorus with
$24.98 \mathrm{~kg} \mathrm{ha}^{-1}$, in this order. However, the sequence of the balance of nutrients was: potassium with an excess of $650.32 \mathrm{~kg} \mathrm{ha}^{-1}$, phosphorus with excess of $618.00 \mathrm{~kg} \mathrm{ha}^{-1}$, nitrogen with deficit of $-172.0 \mathrm{~kg} \mathrm{ha}^{-1}$, calcium with deficit of $-673.41 \mathrm{~kg} \mathrm{ha}^{-1}$ and magnesium with deficit of $-737.09 \mathrm{~kg} \mathrm{ha}^{-1}$, in this order.

Forage cactus extracts approximately $360 \mathrm{~kg}$ of $\mathrm{N}, 64 \mathrm{~kg}$ of $\mathrm{P}, 1,032 \mathrm{~kg}$ of K and $940 \mathrm{~kg}$ of Ca, per hectare every two years, without considering the other macro- and micronutrients (DUBEUX JÚNIOR et al., 2010). Thus, if there is no replenishment of nutrients through fertilization, there will be a reduction in the yield and quality of the forage.

\section{Manganese concentration in cladodes}

Figure 6 shows that the Mn exports did not fit to any of the tested regression models, showing an overall mean content of $1,616.71 \mathrm{mg} \mathrm{kg}^{-1}$ of dry matter $\left(16.16 \mathrm{~kg} \mathrm{ha}^{-1}\right.$ of Mn for every $10 \mathrm{t} \mathrm{ha}^{-1}$ of dry matter). The maximum $\mathrm{Mn}$ exported of $\mathrm{Mn}$ at 375 DAP was $112.18 \mathrm{~kg} \mathrm{ha}^{-1}$.

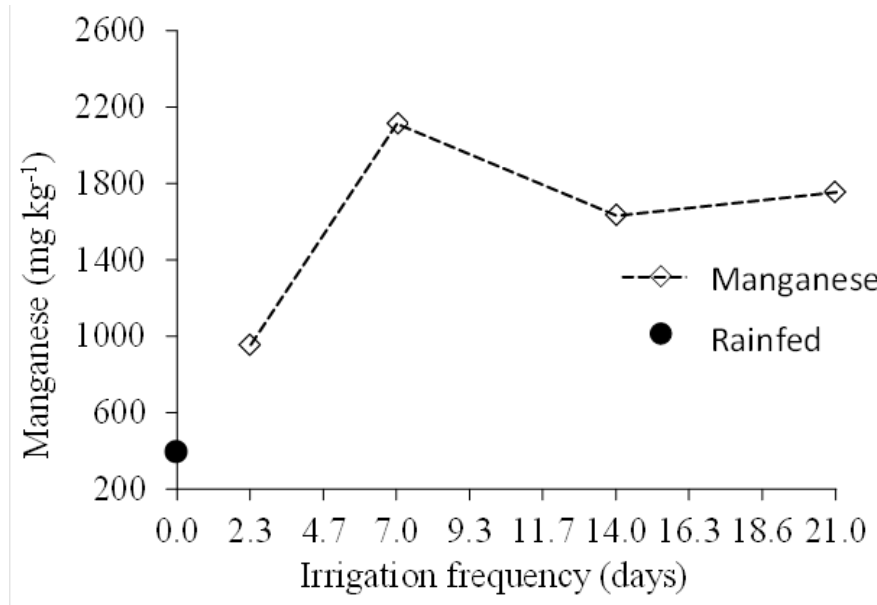

Figure 6. Manganese concentration of forage cactus plants (cladodes) at 375 DAP differing in irrigation frequency.

Donato et al. (2016), studying bovine manure doses and spacing, obtained at 600 DAP mean extraction of $6.61 \mathrm{~kg} \mathrm{ha}^{-1}$ for every $10 \mathrm{t} \mathrm{ha}^{-1}$ of dry matter. Souza (2015) observed that the Mn contents of $2,006.06$ and $1,761.01 \mathrm{mg} \mathrm{kg}{ }^{-1}$, resulted from NPK and NP fertilizations over 620 DAP, respectively, did not differ and exceeded the contents of the treatments without fertilization (984.41 $\mathrm{mg} \mathrm{kg}^{-1}$ ) and when fertilized with $\mathrm{P}$ $\left(665.65 \mathrm{mg} \mathrm{kg}^{-1}\right)$. Our results show that there was a mean overall $\mathrm{Mn}$ export of $13.54 \mathrm{~kg} \mathrm{ha}^{-1}$ for every $10 \mathrm{t} \mathrm{ha}^{-1}$ of dry matter.

The irrigation interval of 2.3 days was the only treatment that did not show significant statistical differences $(\mathrm{P}>0.05)$, but the other irrigation intervals of 7,14 and 21 days showed significant statistical difference $(\mathrm{P}<0.05)$ compared to the rainfed cultivation for $\mathrm{Mn}$ exportation at 375 DA. This demonstrates that the treatment with highest irrigation frequency irrigated with sewage effluent led to higher $\mathrm{Mn}$ content in the soil. The increase in soil $\mathrm{pH}$ substantially reduced the $\mathrm{Mn}$ concentration in the soil solution. Otherwise, the reduction of $\mathrm{pH}$, as occurred in the experiment, leads to greater availability of $\mathrm{Mn}$ concentration in the soil solution before undergoing oxidation to unavailable forms and, consequently, to higher $\mathrm{Mn}$ extraction/exportation. The greater absorption of $\mathrm{Mn}$ in comparison to other metal ions possibly occurred because the soil $\mathrm{pH}$ was acidic, due to the influence of the organic matter applied via fertigation and particularly via basal fertilization.

However, considering the mean values of dry matter production, $\mathrm{Mn}$ exports at $375 \mathrm{DAP}$ were in 
the order of $53.85,163.67,107.71$ and $73.98 \mathrm{~kg} \mathrm{ha}^{-1}$ for the irrigation intervals of $2.3,7,14$ and 21 days, respectively, i.e., 9.57, 21.17, 16.36 and $17.58 \mathrm{~kg} \mathrm{ha}^{-1}$ of Mn for every $10 \mathrm{t} \mathrm{ha}^{-1}$ of dry matter in the irrigation intervals at $375 \mathrm{DAP}$, respectively.

Donato et al. (2017) studied the effects of bovine manure doses and spacing on forage cactus mineral extraction and found at 600 DAP, the mean $\mathrm{Mn}$ contents in the order of $23.17 \mathrm{~kg} \mathrm{ha}^{-1}$. The fitted model estimates that the maximum $\mathrm{Mn}$ export (34.32 $\mathrm{kg} \mathrm{ha}^{-1}$ ) occurred at the dose of 200-150-100 (NPK). Souza (2015), in an experiment with N, NP and NPK fertilization at 620 DAP, obtained a mean export of $12.07 \mathrm{~kg} \mathrm{ha}^{-1}$. Maximum $\mathrm{Mn}$ exports in forage cactus occurred in the treatment with spacing of $2.0 \times 0.25$, equal to $13.82 \mathrm{~kg} \mathrm{ha}^{-1}$.

\section{Sodium concentration in cladodes}

In the forage cactus, $\mathrm{Na}^{+}$exports did not fit to any of the tested regression models and the overall mean was equal to $452.26 \mathrm{mg} \mathrm{kg}^{-1}$ of dry matter (Figure 7). The maximum $\mathrm{Na}$ extraction was obtained through the mean $\mathrm{Na}$ export (452.26 mg kg ${ }^{-1}$ ) and the mean value of total dry matter production $\left(69.39 \mathrm{t} \mathrm{ha}^{-1}\right)$ at $375 \mathrm{DAP}$, being equal to $31.38 \mathrm{~kg} \mathrm{ha}^{-1}$. The mean $\mathrm{Na}$ exportation was $4.52 \mathrm{~kg} \mathrm{ha}^{-1}$ for every $10 \mathrm{tha}^{-1}$ of dry matter.

Values much lower than those found in the present study were reported by Galizzi, Felker and Gonzalez (2004), of $38.0 \mathrm{mg} \mathrm{kg}{ }^{-1}$, in experiment conducted in Argentina. Although $\mathrm{Na}$ is not usually considered as essential to plants, Epstein and Bloom (2006) claim in their review that $\mathrm{Na}$ is a micronutrient for plants with CAM carbon fixation pathway, such as forage cactus, because it is essential for the regeneration of phosphoenolpyruvate, the substrate of the first carboxylation in this pathway. Still, according to these authors, $\mathrm{Na}$ deficiency induces chlorosis and necrosis in these plants, as well as failures in flower formation.

Donato et al. (2016), studying bovine manure doses and spacing in forage cactus obtained an overall mean $\mathrm{Na}$ extraction of $0.45 \mathrm{~kg} \mathrm{ha}^{-1}$ for every $10 \mathrm{t} \mathrm{ha}^{-1}$ of dry matter at 600 DAP. Souza (2015), in an experiment with NPK fertilization, found overall mean $\mathrm{Na}$ exportation of $0.40 \mathrm{~kg} \mathrm{ha}^{-1}$ for every $10 \mathrm{tha}^{-1}$ of dry matter at 620 DAP.

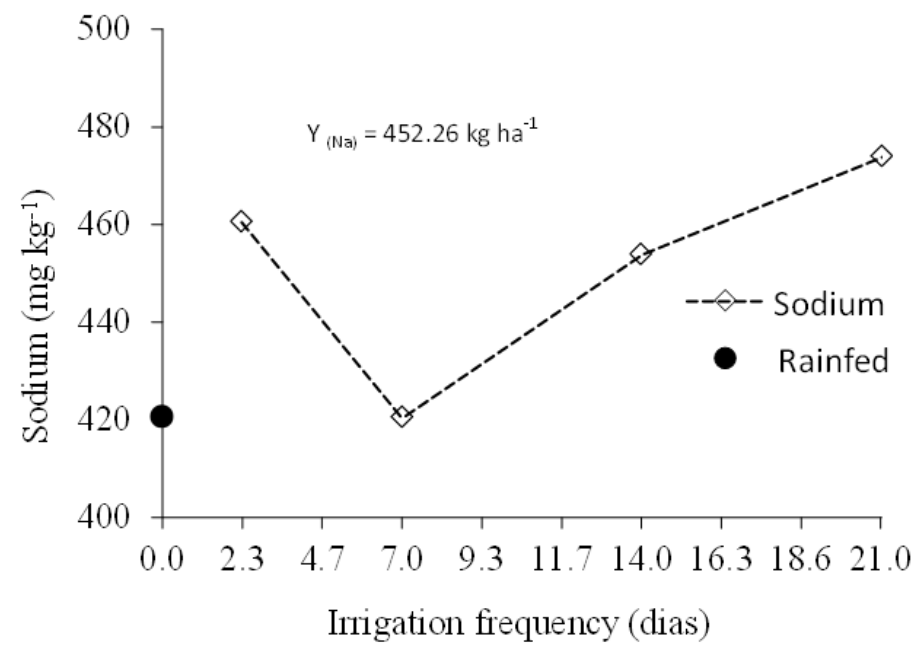

Figure 7. Sodium concentration of forage cactus plants (cladodes) at 375 DAP differing in irrigation frequency.

None of the irrigation intervals showed significant statistical differences $(\mathrm{P}<0.05)$ when compared to the control, under rainfed conditions for $\mathrm{Na}$ exportation at $375 \mathrm{DAP}$. This demonstrates the small contribution of this nutrient from basal fertilization and fertigation to $\mathrm{Na}$ accumulation in the soil and, consequently, its export by the plant.

However, considering the mean values of dry matter production, $\mathrm{Na}$ extractions at 375 DAP were in the order of 25.93, 32.52, 29.89 and $19.95 \mathrm{~kg} \mathrm{ha}^{-1}$ in the irrigation intervals of $2.3,7,14$ and 21 days, respectively, i.e., 4.61, 4.21, 4.54 and $4.74 \mathrm{~kg} \mathrm{ha}^{-1}$ of $\mathrm{Na}$ for every $10 \mathrm{t} \mathrm{ha}^{-1}$ of dry matter in the irrigation intervals at $375 \mathrm{DAP}$, respectively.

Donato et al. (2017) studied bovine manure doses and obtained at 600 DAP a mean Na content of $0.69 \mathrm{~kg} \mathrm{ha}^{-1}$. The fitted model estimates a maximum $\mathrm{Ca}$ exportation of $0.87 \mathrm{~kg} \mathrm{ha}^{-1}$ at the dose of 000-000-000 (NPK). Souza (2015), in experiment with N, NP and NPK fertilization at 620 DAP, obtained mean exportation of $0.84 \mathrm{~kg} \mathrm{ha}^{-1}$ of $\mathrm{Na}$. Maximum $\mathrm{Na}$ exportation occurred in the treatment with spacing of $1.0 \times 0.50$, equal to $1.05 \mathrm{~kg} \mathrm{ha}^{-1}$.

This present study has shown that forage cactus is water and nutrient demanding in edaphoclimatic conditions, since its productive potential can be increased by two times when these conditions are provided. This demonstrates the fragility of the soils and their deterioration over some crop cycles without proper care. 


\section{CONCLUSIONS}

There was a significant effect of the intervals between irrigation events on the contents of $\mathrm{Ca}$ and $\mathrm{Mg}$. The highest contents of $\mathrm{Ca}$ and $\mathrm{Mg}$ were found with irrigation frequency of 2.3 days, using the public-supply water;

The macronutrients concentration in largest amounts by forage cactus were $\mathrm{N}$ and $\mathrm{K}$, followed by $\mathrm{Ca}, \mathrm{Mg}$ and $\mathrm{P}$. The nutritional balance indicated an excess of $\mathrm{K}$ and $\mathrm{P}$, and deficit of $\mathrm{N}, \mathrm{Ca}$ and $\mathrm{Mg}$, in this order.

The increment of bovine manure doses in all treatments improved forage cactus quality and production, promoting greater extraction of nutrients and increase in their contents in the cladodes.

\section{REFERENCES}

ALVES, R. N. et al. Produção de forragem pela palma após 19 anos sob diferentes intensidades de corte e espaçamentos. Revista Caatinga, Mossoró, v. 20, n. 4, p. 38-44, 2007.

DONATO, P. E. R. et al. Nutrition and yield of 'Gigante' cactus pear cultivated with different spacings and organic fertilizer. Revista Brasileira de Engenharia Agrícola e Ambiental, Campina Grande, v. 20, n. 12, p. 1083-1088, 2016.

DONATO, P. E. R. et al. Extraction/exportation of macronutrients by cladodes of 'Gigante' cactus pear under different spacings and organic fertilization. Revista Brasileira de Engenharia Agrícola e Ambiental, Campina Grande, v. 21, n. 4, p. 238-243, 2017.

DUBEUX JÚNIOR, J. C. B. et al. Adubação mineral no crescimento e 77 composição mineral da palma forrageira-Clone IPA-20. Revista Brasileira de Ciências Agrárias, Recife, v. 5, n. 1, p. 129-135, 2010.

EMPRESA BRASILEIRA DE PESQUISA AGROPECUÁRIA - EMBRAPA. Manual de métodos de análise de solo. 2. ed. Rio de Janeiro, RJ: Centro Nacional de Pesquisas De Solos, 1997. $221 \mathrm{p}$.

EPSTEIN, E.; BLOOM, A. J. Nutrição mineral de plantas: princípios e perspectivas. Londrina, PR: Editora Planta, 2006. 403 p.

ERNANI, P. R. et al. Potássio. In: NOVAIS, R. F. et al. (Eds.). Fertilidade do Solo. 1. ed. Viçosa, MG: Sociedade Brasileira de Ciência do Solo, 2007. cap. 9, p. 551-594.
ERTHAL, V. J. et al. Alterações físicas e químicas de um Argissolo pela aplicação de água residuária de bovinocultura. Revista Brasileira de Engenharia Agrícola e Ambiental, Campina Grande v. 14, n. 5, p. 467-477, 2010.

GALIZZI, F. A.; FELKER, P.; GONZÁLEZ, C. Correlations between soil and cladode eensoil and cladode nutriente concentrations and fruit yield and quality in cactus pears, Opuntia ficus indicain a traditional farm setting in Argentina. Journal of Arid Environments, Trelew, v. 59, n. 1, p. 115-132, 2004.

LOPES, R. A. et al. Doses, fontes e épocas de aplicação de nitrogênio em arroz de terras altas cultivado em sistema de semeadura direta. Revista Caatinga, Mossoró, v. 26, n. 4, p. 79-87, 2013.

NOBEL, P. S. et al. Nutrient relations and producitivity of prickly pear cacti. Agronomy Journal, Madison, v. 79, n. 3, p. 550-555, 1987.

SANTOS, D. C. et al. Manejo e utilização da palma forrageira (Opuntia e Nopalea) em Pernambuco: cultivo e utilização. 1. ed. Recife, PE: IPA, 2002. 45 p.

SANTOS, M. V. F. et al. Estudo comparativo das cultivares de palma forrageira "gigante", "Redonda" (Opuntia ficus-indica Mill) e "Miúda" (Nopalea cochenillifera Salm-Dick) na produção de leite. Revista da Sociedade Brasileira de Zootecnia, Viçosa, v. 19, n. 6, p. 504-511, 1990.

SILVA, A. R. A. et al. Trocas gasosas em plantas de girassol submetidas à deficiência hídrica em diferentes estádios fenológicos. Revista Ciência Agronômica. Fortaleza, v. 44, n. 1, p. 86-93, 2013.

SOUZA, T. C. Sistemas de cultivo para a palma forrageira cv. Miúda (Nopalea cochenillifera Salm Dyck). 2015. 119 f. Tese (Doutorado Integrado em Zootecnia: Área de Concentração em Forragicultura) - Universidade Federal Rural de Pernambuco, Recife, 2015.

TELES, M. M. et al. Efeitos da adubação e de nematicida no crescimento e na produção da palma forrageira (Opuntia fícus-indica Mill.) cv. Gigante. Revista Brasileira de Zootecnia, Viçosa, v. 31, n. 1, p. 52-60, 2002.

TELES M. M. et al. Efeito da adubação e do uso de nematicida na composição química da palma forrageira (Opuntia ficus indica Mill). Revista Brasileira de Zootecnia, Viçosa, v. 33, n. 6, p. 1992 $-1998,2004$. 
TEDESCO, M. J. et al. Análise de solo, plantas e outros materiais. 2. ed. Porto Alegre: Departamento de Solos da Universidade Federal do Rio Grande do Sul, 1995. 174 p. (Boletim Técnico de Solos, 5). 